in our patient, however, occurred in the absence of such stimulation. Myoclonus as defined by Gastaut ${ }^{3}$ may occur as a result of any lesion from the motor cortex to the spinal motor neurone, but these movements were not myoclonic in our patient. The patient described by Campbell and Garland" with subacute myoclonic spinal neuronitis had more rapid myoclonus in the legs associated with fever and possible spinal cord infarction. Our patient's involuntary movements fit Hughlings Jackson's description of focal epilepsy. ${ }^{1}$ Nittner ${ }^{5}$ states that epileptic seizures are rarely caused by spinal cord tumours but reviewing the case reports he found these seizures restricted to patients with tumours around the foramen magnum. Gowers ${ }^{2}$ cites Brown-Sequard's comment that "spinal epilepsy" is a suitable description for a violent muscle spasm followed by clonic movements occurring in a patient with a known spinal cord lesion.

There is no other published description of spinal epilepsy with such a clear focal motor event occurring in a patient with a spinal lesion. Immediate cessation of these attacks after the removal of the meningioma emphasised the cause and effect relation.

We acknowledge the help of Mr S G Galbraith, who performed the laminectomy, Dr E Teasdale, who performed the radiology, and Mrs M McColl for secretarial work.

1 Taylor J, ed. Sclected writings of Fohn Hughlings fackson. Vol 1. London: Hodder and Stoughton, 1931.

2 Gowers RW. A manual of diseases of the nervous system. Vol 1. 2nd ed. London: J and A Churchill, 1892.

${ }^{3}$ Gastaut, H. Dictionary of epilepsy. Part 1: Definitions. Geneva: WHO, 1973.

4 Campbell AMG, Garland H. Subacute myoclonic spinal neuronitis. 7 Neurol Neurosurg Psychiatry. 1956;19:268-74

${ }^{5}$ Nittner K. Spinal meningiomas, neurinomas, neurofibromas and hour glass tumours. In: Vinken PJ, Bruyn GW, eds. Handbook of clinical neurology. Amsterdam: North Holland Publishing Co, 1976; 20:199.

(Accepted 25 February 1981)

Department of Neurology, Institute of Neurological Sciences, Southern General Hospital, Glasgow G51 4TF

M HARRINGTON, MB, MRCP, registrar

I BONE, MB, MRCP, consultant

\section{Postoperative legionella pneumonia diagnosed by percutaneous lung aspiration}

Isolation of Legionella pneumophila is often difficult, and a definitive diagnosis of legionella pneumonia may depend on serological tests. We describe a patient with postoperative pneumonia, presumably acquired in hospital, in which the diagnosis was established by percutaneous lung aspiration.

\section{Case report}

A 62-year-old man who presented with an 18-month history of breathlessness and giddiness was found to have aortic stenosis and coronary artery disease. On 26 September 1980 he was admitted for aortic valve replacement and a coronary artery bypass graft. After a successful operation on 30 September he was transferred to the intensive care unit and returned to the ward on 2 October. Prophylaxis for the operation was the standard regimen of penicillin, flucloxacillin, and gentamicin, which was continued for three days. During this time he had a low-grade fever but was otherwise well. On the fourth day after operation he complained of weakness and cough with tenacious purulent sputum, his temperature reached a maximum of $38.7 \mathrm{C}$ and peripheral white cell count rose to $21.0 \times 10^{9} / 1$ with $75 \%$ neutrophils. A chest radiograph on 7 October showed consolidation in the anterior segment of the right upper lobe and the antibiotic regimen was restarted. By 10 October there was pronounced clinical and radiological deterioration, and percutaneous aspiration of the right upper lobe was performed using a 19-G needle with $2-\mathrm{ml}$ saline flush. The centrifuged deposit of the fluid showed leucocytes and numerous poorly staining Gram-negative rods, many of them present intracellularly and in clusters. They resembled Legionella, and showed fluorescence by indirect fluorescence antibody test using legionella serogroup 1 antiserum. Treatment was immediately changed to erythromycin $1 \mathrm{~g}$ intravenously every six hours. Within two days the patient greatly improved, the temperature was normal, and the white cell count had fallen to $12 \cdot 8 \times 10^{9} / 1$. Subsequently thrombophlebitis at multiple drip sites proved troublesome, and after 10 days oral treatment was substituted (erythromycin $1 \mathrm{~g} 6$-hourly). The patient continued to run a low-grade fever, possibly due to thrombophlebitis, but was generally well at the time of discharge on 26 October.

During his illness the patient remained orientated though slow in his reactions. The plasma sodium was normal on admission but fell after operation to $120 \mathrm{mmol}(120 \mathrm{mEq}) / 1$. Culture of lung aspirate on charcoalyeast extract agar ultimately grew $L$ pneumophila serogroup 1 . Blood and sputum cultures were negative. Serum obtained on 10 October was negative for legionella antibodies, but serum taken six days later showed an IgM titre of more than $1 / 540$ and an IgG titre of $1 / 30$ to L pneumophila serogroup 1 .

\section{Comment}

This case shows the usefulness of percutaneous lung aspiration in diagnosing legionella pneumonia when routine cultures and serological tests are negative. This postoperative pneumonia failed to respond to a common antibiotic combination though it showed no particular features suggestive of legionnaires' disease. Hyponatraemia developed after operation when the patient was receiving diuretics, but features such as mental confusion, chest or abdominal pain, and diarrhoea were absent. Percutaneous lung aspiration is a simple technique, and although small haemoptyses and shallow pneumothoraces occur in a few patients specific treatment is rarely needed. ${ }^{1}$

Since the incubation period of legionnaires' disease is usually 2-10 days, this patient probably acquired his infection in hospital. Legionnaires' disease may result from intermittent use of heavily contaminated shower units, ${ }^{2}$ but this patient used only a bath. In the operating theatre he was on closed-circuit breathing apparatus and would not have been at risk. In the ventilation shaft serving the intensive care unit humidification was provided by a spinning disc system using deionised water, culture of which failed to grow legionella ( $\mathrm{Dr} \mathbf{J}$ B Kurtz, personal communication). The precise route of infection remains uncertain, though suspicion lies with the bath water, $L$ pneumophila having been isolated from the hospital cold water system. No other nosocomial cases of legionnaires's disease have been recognised since this hospital was opened.

We thank Professor P Sleight for permission to publish this case report.

${ }^{1}$ Davidson M, Tempest B, Palmer DL. Bacteriological diagnosis of acute pneumonia. Comparison of sputum, transtracheal aspirates and lung aspirates. f $A M A$ 1976;235:158-63.

2 Tobin JO'H, Beare J, Dunnill MS, et al. Legionnaires' disease in a transplant unit: isolation of the causative agent from shower baths. Lancet 1980;ii :118-21.

(Accepted 18 February 1981)

Departments of Medicine and Microbiology, John Radcliffe Hospital, Oxford OX3 9DU

M K BENSON, MD, MRCP, consultant physician

R G MITCHELL, DM, FRCP, consultant microbiologist

M PHILLIPS, MB, MRCP, medical registrar

\section{Calcium and calciferol antagonise effect of verapamil in atrial fibrillation}

Verapamil is an antiarrhythmic and antianginal drug used increasingly to control supraventricular arrhythmias. We report on a patient successfully treated with verapamil for atrial fibrillation of long duration in whom atrial fibrillation reappeared after the ingestion of calcium and calciferol. The patient reconverted to sinus rhythm after the intravenous administration of verapamil, fluids, and frusemide.

\section{Case report \\ Atrial fibrillation developed in a 70-year-old woman with a seven-year history of grade 1 functional calcific aortic stenosis, a $20 \mathrm{~mm} \mathrm{Hg}$ aortic valve gradient, and systemic hypertension. Because of hypersensitivity to digoxin and quinidine verapamil was started. Two days later she converted to sinus rhythm. Serum calcium concentration was $2.45 \mathrm{mmol} / 1(9.8 \mathrm{mg} / 100 \mathrm{ml})$. During 13 months of treatment with verapamil her clinic visits averaged 1.5 per month. Each visit included a complete physical examination and electrocardiography. Both showed normal cardiac sinus rhythm. Because of diffuse osteoporosis calcium adipinate $1.2 \mathrm{~g}$ /day and calciferol $3000 \mathrm{IU} /$ day (Destrol Calcium, Teva) were prescribed.}


A week later atrial fibrillation reappeared and her blood calcium concentration had risen to $2.7 \mathrm{mmol} / 1(10.8 \mathrm{mg} / 100 \mathrm{ml})$. Frusemide $20 \mathrm{mg}$ and $500 \mathrm{ml}$ physiological saline were administered intravenously. Carotid massage was performed without success. Repeated doses of frusemide $20 \mathrm{mg}$ and $5 \mathrm{mg}$ verapamil (injected slowly) were given intravenously. Nine minutes later her cardiac rhythm converted to sinus rhythm. Serum calcium concentration was $2.55 \mathrm{mmol} / 1(10.2 \mathrm{mg} / 100 \mathrm{ml})$. She was advised to stop taking the supplementary calcium and calciferol.

\section{Comment}

Verapamil is an antiarrhythmic and antianginal drug used to control supraventricular arrhythmias and the anginal syndrome. Fleckenstein showed that verapamil inhibited the transmembranal influx of calcium into cardiac cells and the release of calcium from the endoplasmic reticulum, ${ }^{1}$ causing a negative inotropic effect. This effect may be reversed by increasing the extracellular concentration of calcium or promoting its transmembranal influx with catecholamines. ${ }^{12}$

Successful resuscitation of patients poisoned with intravenous calcium has been reported. ${ }^{3}$ Verapamil is beneficial in atrial fibrillation because it slows the conduction of impulses through the atrioventricular junction by a direct cellular effect that is unrelated to autonomic influences. ${ }^{4}$ Our patient was successfully treated with verapamil when atrial fibrillation recurred after the ingestion of calcium and calciferol in doses that lead to hypercalcaemia. The appearance of atrial fibrillation prompted a dual therapeutic approach aimed at reducing her blood calcium concentration while increasing her blood verapamil concentration. This was based on the assumption that hypercalcaemia antagonises the effect of verapamil on the atrioventricular node and favours re-entrant currents. We suggest that calcium should be used cautiously in patients receiving verapamil. In the event of "calcium poisoning" calcium intake should be stopped, hypercalcaemia treated, and a supplemental dose of verapamil administered if a toxic dose has not been reached.

${ }^{1}$ Fleckenstein A. Specific inhibitors and promoters of calcium action in the excitation contraction coupling of heart muscle and their role in the prevention of production of myocardial lesions. In: Harris P, Opie L, eds. Calcium and the heart. London: Academic Press, 1971:135-8.

2 Grossman A, Furchgott RF. The effects of various drugs on calcium exchange in the isolated guinea pig left auricle. F Pharmacol Exp Ther $1964 ; 145: 162-72$.

${ }^{3}$ Perkins CM. Serious verapamil poisoning: treatment with intravenous calcium gluconate. $\mathrm{Br}$ Med $\mathcal{f} 1978$;ii:1127.

4 Wit AL, Cranfield PF. Effects of verapamil on the sinoatrial and atrioventricular nodes of the rabbit and the mechanism by which it arrests re-entrant AV nodal tachycardia. Circ Res 1974 ;35:413-25.

(Accepted 18 February 1981)

Golan Heights Community Clinics, National Health Services, Israel

BAR-OR DAVID, MD, family practitioner (present appointment : resident in emergency medicine, Denver General Hospital, Denver, Colorado, USA) GASIEL YOEL, MD, family practitioner

\section{Fatal fat embolism after minor trauma}

The clinical fat embolism syndrome-classically breathlessness, tachypnoea, fever, petechial rash, tachycardia, and cerebral effects-is well recognised in trauma. The severity of the syndrome is generally directly related to the degree of trauma. ${ }^{1}$ Cases are usually seen in accident units and orthopaedic wards. I describe three patients admitted to general medical wards who were found to have severe systemic fat embolism after minor trauma. In each case the diagnosis was made only at necropsy.

\section{Case reports}

Case 1-An 80-year-old man was found semiconscious in the toilet of a local lodging house. Chest radiography showed a "snowstorm" appearance, which is a recognised feature of fat embolism (table). He died five hours after admission. At necropsy a bruise $8 \mathrm{~cm}$ diameter was noted in the scalp, but there was no skull fracture.
Case 2-A 23-year-old woman with spina bifida suffered a minor injury to her left chest when she was dropped while being carried. She became W progressively breathless and was admitted 24 hours later. She died three hours after admission despite $35 \%$ oxygen. No fracture was found at necropsy but there was severe kyphoscoliosis with a hypoplastic left lung. Case 3-A 62-year-old man who had suffered from atypical multiple $c$ sclerosis for 15 years fell and hit his head in the bathroom. He became $\widetilde{\Omega}$ progressively breathless and despite $35 \%$ oxygen died five hours after admission to hospital. At necropsy no skull fracture or scalp bruise was identified.

Details of three patients studied

\begin{tabular}{|c|c|c|c|c|}
\hline $\begin{array}{l}\text { Case } \\
\text { No }\end{array}$ & $\begin{array}{l}\text { Age } \\
\text { and } \\
\text { sex }\end{array}$ & $\begin{array}{l}\text { Clinical } \\
\text { features }\end{array}$ & $\begin{array}{l}\text { Evidence of } \\
\text { trauma }\end{array}$ & $\begin{array}{l}\text { Necropsy } \\
\text { findings }\end{array}$ \\
\hline 1 & $80 \mathrm{M}$ & $\begin{array}{l}\text { Cyanosis, coma, } \\
\text { "snowstorm" on } \\
\text { chest radiography }\end{array}$ & $\begin{array}{l}\text { Large scalp bruise, } \\
\text { no skull fracture }\end{array}$ & $\begin{array}{l}\text { Severe fat embolism } \\
\text { in brain, kidneys, } \\
\text { and lungs }\end{array}$ \\
\hline 2 & $23 \mathrm{~F}$ & $\begin{array}{l}\text { Dyspnoea, } \\
\text { tachypnoea, } \\
\text { tachycardia, } \\
\text { cyanosis }\end{array}$ & $\begin{array}{l}\text { History of minor } \\
\text { trauma to ribs }\end{array}$ & $\begin{array}{l}\text { Severe fat embolism } \\
\text { in brain, kidneys, } \\
\text { and lungs }\end{array}$ \\
\hline 3 & $62 \mathrm{M}$ & $\begin{array}{l}\text { Dyspnoea, } \\
\text { tachypnoea, } \\
\text { tachycardia, } \\
\text { cyanosis }\end{array}$ & $\begin{array}{l}\text { History of fall with } \\
\text { minor head injury }\end{array}$ & $\begin{array}{l}\text { Severe fat embolism } \\
\text { in brain, kidneys, } \\
\text { and lungs }\end{array}$ \\
\hline
\end{tabular}

\section{Comment}

All three patients had signs or symptoms consistent with a clinical fat $N$ embolism syndrome, though in no case was the diagnosis suspected. At necropsy all showed evidence of severe fat embolism, which was $\vec{O}$ the cause of death. Although there was evidence or a good history of of trauma, it was apparently minor and there was neither clinical, ف radiological, nor pathological evidence of any appreciable bony 음 injury. The cases were also characterised by a rather fulminating $\overrightarrow{\vec{\sigma}}$ clinical course.

Most evidence at present supports the original suggestion that the fat is derived from the marrow. ${ }^{2}$ Certainly most cases are seen in people with a fracture or multiple fractures of long bones. In one $\vec{\varphi}$ study of 100 cases, ${ }^{3} 93$ showed multiple fractures or a major fracture $\infty$ of the tibia, femur, or pelvis. In only three patients was no bony injury seen, and all had severe soft-tissue injuries. The present three cases suggest that skeletal trauma, even in the absence of a fracture, can produce fat embolism, presumably due to rupture of small $\bar{\partial}$ vessels in the marrow as a result of forces transmitted along the bones. Such cases, however, would not be expected to have a fulminating course leading to death.

The fat emboli first lodge in the pulmonary capillaries, and it is $\overrightarrow{\bar{O}}$ now established that this may produce subclinical hypoxaemia. In 3 severe systemic fat embolism the arterial oxygen pressure may fall to $50 \mathrm{~mm} \mathrm{Hg}$ or less. ${ }^{45}$ All three patients cited here were cyanosed on admission, indicating appreciable hypoxaemia. Pre-existing lung disease may also be associated with a poor prognosis and predispose to systemic fat embolism. It was interesting to find on reviewing these cases that both men had radiological evidence of severe chronic $\frac{\sigma}{3}$ bronchitis and emphysema, confirmed at necropsy, while the other patient had severe kyphoscoliosis and a hypoplastic left lung.

These cases suggest that even minor trauma may precipitate fat embolism, and that people with pre-existing lung disease may be predisposed to severe effects.

I thank Dr R A Fraser for allowing me to include one of his patients in this report.

${ }^{1}$ Sevitt S. Fat embolism. London: Butterworths, 1962.
2 Watson AJ. Genesis of fat emboli. F Clin Pathol 1970;23, suppl 4:132-42. స్

3 Gurd AL, Wilson RI. The fat embolism syndrome. $\mathcal{F}$ Bone foint Surg (Br) $1974 ; 56$ B : 408- 16.

${ }^{4}$ Ross APJ. The fat embolism syndrome: with special reference to the importance of hypoxia in the syndrome. Ann R Coll Surg Engl 1970;46: 158-71.

5 Prys-Roberts C, Greenbaum R, Nunn JF, Kelman GR. Disturbances of pulmonary function in patients with fat embolism. F Clin Pathol 1970; 23, suppl $4: 143-9$.

(Accepted 3 March 1981)

Department of Histopathology, Withington Hospital, Mancheste M20 8LR

ALASTAIR M LESSELLS, MRCPATH, consultant histopathologist 